\title{
Low IRBIT Levels Are Associated With Chemo-resistance in Gastric Cancer Patients
}

\author{
NOBUHIRO NAKAZAWA ${ }^{1}$, KYOICHI OGATA ${ }^{1}$, TAKEHIKO YOKOBORI ${ }^{2}$, MUNENORI IDE $^{3}$, \\ SEDED BAATAR ${ }^{1}$, YASUNARI UBUKATA ${ }^{1}$, AKIHARU KIMURA ${ }^{1}$, NORIMICHI KOGURE $^{1}$, \\ MAKOTO SOHDA ${ }^{1}$, HIROYUKI KUWANO ${ }^{1}$, HIROSHI SAEKI ${ }^{1}$ and KEN SHIRABE ${ }^{1}$ \\ ${ }^{1}$ Department of General Surgical Science, Gunma University Graduate School of Medicine, Maebashi, Japan; \\ ${ }^{2}$ Department of Innovative Cancer Immunotherapy, Gunma University Graduate School of Medicine, Maebashi, Japan; \\ ${ }^{3}$ Department of Diagnostic Pathology, Gunma University Graduate School of Medicine, Maebashi, Japan
}

\begin{abstract}
Background/Aim: We investigated whether the expression of inositol 1, 4, 5-trisphosphate receptor-binding protein released with inositol 1, 4, 5-trisphosphate (IRBIT) in clinical gastric cancer $(G C)$ patients could predict the therapeutic response to postoperative adjuvant chemotherapy. Materials and Methods: Immunohistochemistry was used to investigate IRBIT expression in 115 GC patients. To clarify whether IRBIT had a relationship with the therapeutic effects of chemotherapy, we compared two groups - 62 patients treated with postoperative adjuvant chemotherapy and 53 patients treated with postoperative adjuvant chemotherapy. Results: Regarding the postoperative adjuvant chemotherapyfree group, we did not find any statistically significant correlation between clinicopathological features and recurrence regardless of the expression of IRBIT. In contrast, in the group receiving postoperative adjuvant chemotherapy, a significant association was found between IRBIT expression and both overall and disease-free survival. Conclusion: IRBIT may be used as a useful predictive marker for chemotherapy.
\end{abstract}

Correspondence to: Kyoichi Ogata, MD, Ph.D., Department of General Surgical Science, Graduate School of Medicine, Gunma University, 3-39-22 Showa-machi, Maebashi 371-8511, Japan. Tel: +81272208224, Fax: +81272208230, e-mail: kogata@gunmau.ac.jp; Takehiko Yokobori, MD, Ph.D., Department of Innovative Cancer Immunotherapy, Graduate School of Medicine, Gunma University, 3-39-22 Showa-machi, Maebashi 371-8511, Japan. Tel: +81272208222, Fax: +81272020212, e-mail: bori45@gunmau.ac.jp; Nobuhiro Nakazawa, MD, Department of General Surgical Science, Graduate School of Medicine, Gunma University, 3-39-22 Showa-machi, Maebashi 371-8511, Japan. Tel: +81 272208224, Fax: +81272208230,e-mail: nakazawa75@yahoo.co.jp

Key Words: 1,4,5-triphosphate receptor-binding protein, IRBIT, gastric cancer, chemoresistance.
Gastric cancer (GC) is one of the most common malignancies and the third-leading cause of malignancyrelated death globally (1). However, the clinical outcome of GC patients has improved their disease-free status following curative resection and postoperative adjuvant chemotherapy (2). Postoperative adjuvant chemotherapy is able to improve the survival rate after surgery; on the other hand, it remains insufficient (3). Therefore, it is important to identify predictors of the therapeutic effect of chemotherapy.

IRBIT (inositol 1, 4, 5-trisphosphate receptor-binding protein released with inositol 1, 4, 5-trisphosphate) was discovered as an inositol 1, 4, 5-trisphosphate receptor (IP3R)binding protein (4). IRBIT is a multifunctional protein that regulates IP3R activation $(5,6)$, intracellular $\mathrm{Ca}^{2+}$ concentration (7), the BCL2L10 antiapoptotic protein (8), ion channels, and ion transporters such as the $\mathrm{Na}^{+} / \mathrm{HCO}_{3}{ }^{-}$cotransporter (9), the $\mathrm{Na}^{+} / \mathrm{H}^{+}$exchanger (10), and the $\mathrm{Cl}^{-} / \mathrm{HCO}_{3}{ }^{-}$exchanger (11). The function of IRBIT is to suppress IP3R activation, leading to reduced IP3-induced $\mathrm{Ca}^{2+}$ levels $(5,6)$. The intracellular $\mathrm{Ca}^{2+}$ concentration regulates many processes as a second messenger, including cell cycle and apoptosis (7). IRBIT promotes apoptosis by inhibiting BCL2L10 and promoting contact between endoplasmic reticulum and mitochondria (8), suggesting that IRBIT is a regulator of cell death. In terms of cancer, Jeong et al. showed that IRBIT functions as a tumor suppressor in human epithelial ovarian cancer (12). Wittig et al. have shown that IRBIT is related to drug resistance against DNA-damaging drugs in a human malignant melanoma cell line (13). However, few studies have addressed the relationship between IRBIT and the therapeutic effects of chemotherapy in GC.

$\mathrm{S}-1$ is an orally active combination of tegafur, gimeracil, and oteracil in a molar ratio of 1:0.4:1 (14). The results of a largescale trial that was called the Adjuvant Chemotherapy Trial of S-1 for Gastric Cancer (ACTS-GC) revealed that the five-year overall survival rate was $71.7 \%$ in the adjuvant $\mathrm{S}-1$ group and $61.1 \%$ in the surgery-only group $(15,16) . \mathrm{S}-1$ was approved 
as an effective adjuvant chemotherapy in patients with stage II or III GC who underwent potentially curative surgery.

The purpose of this study was to clarify the significance of IRBIT in clinical GC patients, particularly those treated with postoperative adjuvant chemotherapy. Therefore, we performed an immunohistochemical analysis to evaluate the expression of IRBIT in GC tissues.

\section{Materials and Methods}

Patients. A total of 115 patients who underwent potentially curative surgery at the Department of General Surgical Science, Gunma University Hospital, between 2000 and 2006 were prospectively collected. To clarify whether IRBIT has a relationship with the therapeutic effects of chemotherapy, two GC groups were compared - a group of 62 patients who had not been treated with postoperative adjuvant chemotherapy and a group of 53 patients who had been treated with postoperative adjuvant chemotherapy. The characteristics of the patients in the two GC groups with and without postoperative adjuvant chemotherapy are shown in Table I. The reasons for not administering postoperative adjuvant chemotherapy were advanced age, a performance status (PS) on the Eastern Cooperative Oncology Group (ECOG) of three or four, comorbid conditions, and the inability to obtain consent. Median age, gender, lymphatic metastasis, and TNM stage differed significantly between the two GC groups with and without postoperative adjuvant chemotherapy. During the study period, the following regimens were administered as postoperative adjuvant chemotherapy: thirty nine cases were administered S-1, four cases received 5-FU, three cases each received UFT (tegafur-uracil) and FAP (5-FU plus Adriamycin plus CDDP), two cases received FP (5-FU plus CDDP), and one case each received SP (S-1 plus CDDP) and S-1 plus Paclitaxel. The postoperative pathological diagnosis of all patients was stage II or III. The GC patients were staged according to the Japanese Classification of Gastric Carcinoma: 3rd English edition, as developed by the Japanese Gastric Cancer Association (17). This study was approved by the institutional review board of Gunma University (approval no. 180246).

Immunohistochemistry. All specimens were cut into $4 \mu \mathrm{m}$ thick sections and mounted on glass slides. All sections were deparaffinized in xylene, rehydrated, and incubated for $30 \mathrm{~min}$ at room temperature in $0.3 \%$ hydrogen peroxide to block endogenous peroxidase activity. After rehydration through a graded series of ethanol treatments, antigen retrieval was carried out in Immunosaver (Nishin EM, Tokyo, Japan) at $98-100^{\circ} \mathrm{C}$ for $45 \mathrm{~min}$. Nonspecific binding sites were blocked by incubation with Protein Block SerumFree (DAKO, Burlingame, CA, USA) for $30 \mathrm{~min}$. Samples were incubated with primary antibody (diluted by DAKO REAL antibody diluent) overnight at $4^{\circ} \mathrm{C}$. The antibody for IRBIT (Proteintech Group Inc., Chicago, IL, USA, Anti-AHCYL1 antibody, 1:200 dilution) was used. Histofine Simple Stain MAX-PO (Multi) Kit (Nichirei, Tokyo, Japan) was used as the secondary antibody. Chromogen 3,3-diaminobenzidine tetrahydrochloride was applied as a $0.02 \%$ solution in $50 \mathrm{mM}$ ammonium acetate-citrate acid buffer ( $\mathrm{pH}$ 6.0) containing $0.005 \%$ hydrogen peroxide. The sections were lightly counterstained with hematoxylin and mounted.

The tissue sections were evaluated by two independent evaluators who were blinded to the patient data. We focused on the expression
Table I. Characteristics of 115 GC patients divided into two groups, those who received (+) and those who did not receive (-) postoperative adjuvant chemotherapy.

\begin{tabular}{|c|c|c|c|}
\hline & \multicolumn{3}{|c|}{ Adjuvant chemotherapy } \\
\hline & $\begin{array}{c}(-) \\
\mathrm{n}=62\end{array}$ & $\begin{array}{c}(+) \\
\mathrm{n}=53\end{array}$ & $p$-Value \\
\hline Age (years) & 69 & 60 & $<0.0001 *$ \\
\hline \multicolumn{4}{|l|}{ Gender } \\
\hline Male & 47 & 30 & $0.029^{*}$ \\
\hline Female & 15 & 23 & \\
\hline \multicolumn{4}{|l|}{ Histology } \\
\hline Well, Moderate & 25 & 18 & 0.48 \\
\hline Poor, Signet & 37 & 35 & \\
\hline Tumor size (mm) & 69 & 69 & 0.97 \\
\hline \multicolumn{4}{|l|}{ Depth } \\
\hline $\mathrm{m}, \mathrm{sm}, \mathrm{mp}$ & 9 & 7 & 0.84 \\
\hline ss, se, si & 53 & 46 & \\
\hline \multicolumn{4}{|l|}{ Lymphatic metastasis } \\
\hline Absent & 16 & 6 & $0.045^{*}$ \\
\hline Present & 46 & 47 & \\
\hline \multicolumn{4}{|l|}{ Lymphatic invasion } \\
\hline Absent & 6 & 1 & 0.065 \\
\hline Present & 56 & 52 & \\
\hline \multicolumn{4}{|l|}{ Venous invasion } \\
\hline Absent & 46 & 38 & 0.76 \\
\hline Present & 16 & 15 & \\
\hline \multicolumn{4}{|l|}{ Stage } \\
\hline II & 34 & 18 & $0.024^{*}$ \\
\hline III & 28 & 35 & \\
\hline \multicolumn{4}{|l|}{ HER2 } \\
\hline Negative & 55 & 46 & 0.57 \\
\hline Positive & 5 & 6 & \\
\hline \multicolumn{4}{|l|}{ IRBIT } \\
\hline Low expression & 16 & 10 & 0.37 \\
\hline High expression & 46 & 43 & \\
\hline \multicolumn{4}{|l|}{ Regimens } \\
\hline S-1 & - & 39 & - \\
\hline $5-\mathrm{FU}$ & - & 4 & \\
\hline UFT & - & 3 & \\
\hline 5-FU+Adr+CDDP & - & 3 & \\
\hline 5-FU+CDDP & - & 2 & \\
\hline S-1+PTX & - & 1 & \\
\hline $\mathrm{S}-1+\mathrm{CDDP}$ & - & 1 & \\
\hline
\end{tabular}

Well: Well differentiated; Moderate: moderately differentiated; Poor: poorly differentiated; Signet: signet ring cell; Adr: Adriamycin; CDDP: cisplatin; PTX: paclitaxel. ${ }^{*} p<0.05$.

of IRBIT in cancer cells and evaluated them using the Allred score (18). The proportion of stained cells was divided into six categories (0: completely negative; $1:<1 \%$ positive; $2: 1-10 \%$ positive; $3: 11-$ $33 \%$ positive; $4: 34-66 \%$ positive; and $5: 67-100 \%$ positive). The intensity of the most predominant area was divided into three categories ( 0 : no staining; 1 : weak positive staining; 2 : moderate positive staining; 3 : strong positive staining). The proportion and intensity scores were added, and the cutoff level was $\geq 5$ as a high expression group in this study. 

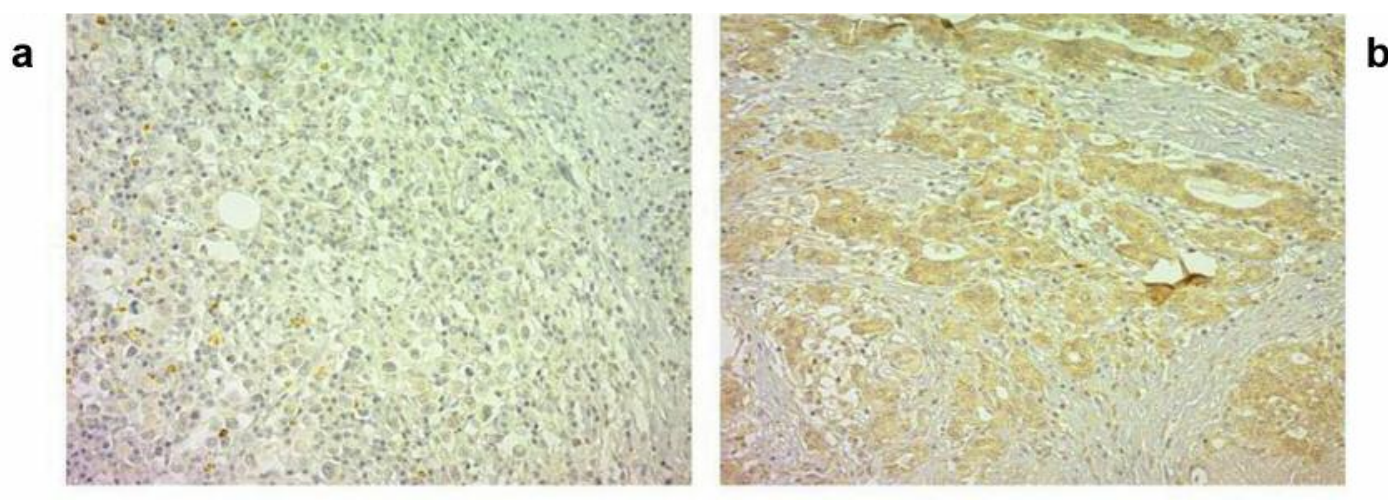

Figure 1. Representative pictures of immunohistochemical staining of IRBIT with GC tissues per field at 200x. (a) The expression of IRBIT was negative in cancerous tissue. (b) The expression of IRBIT was positive in cancerous tissue.

\section{a}
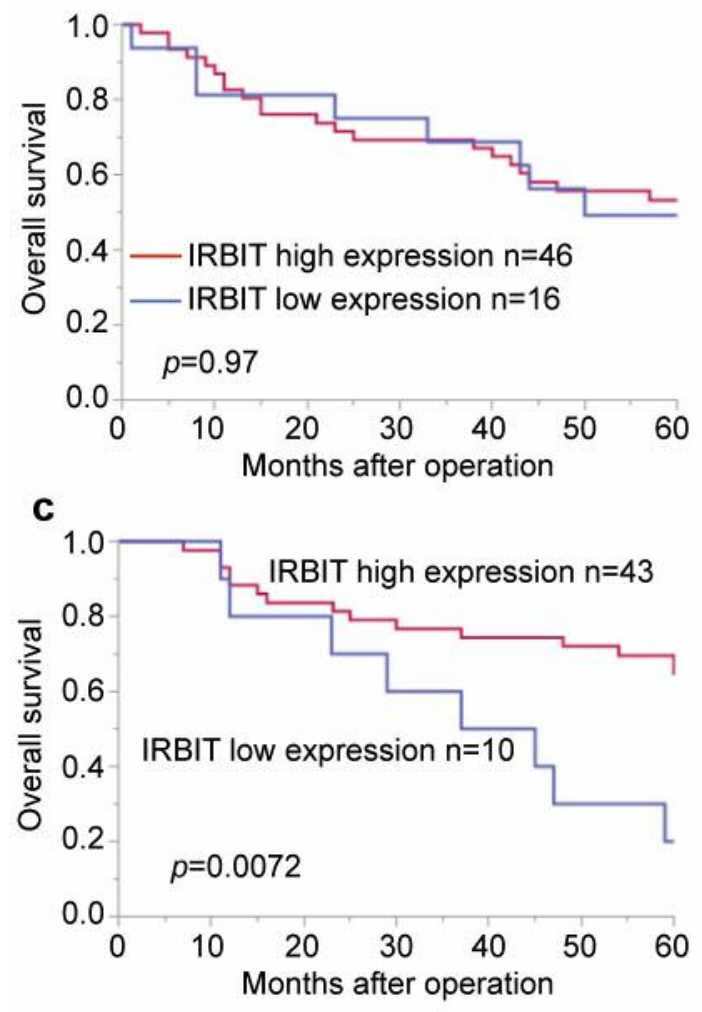

b

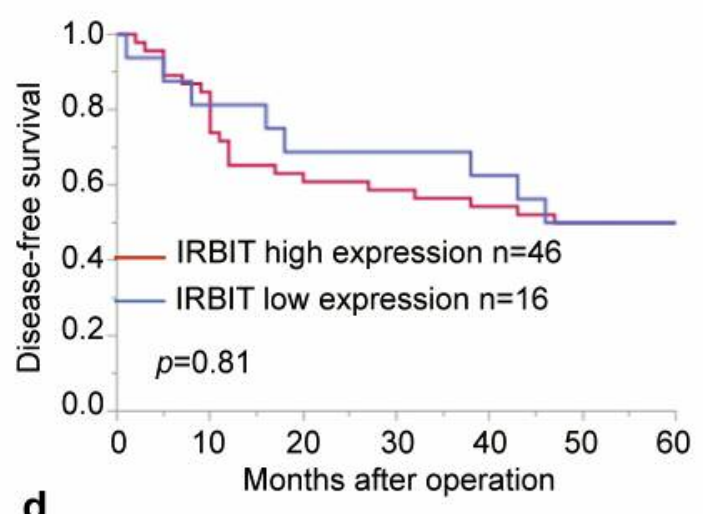

d

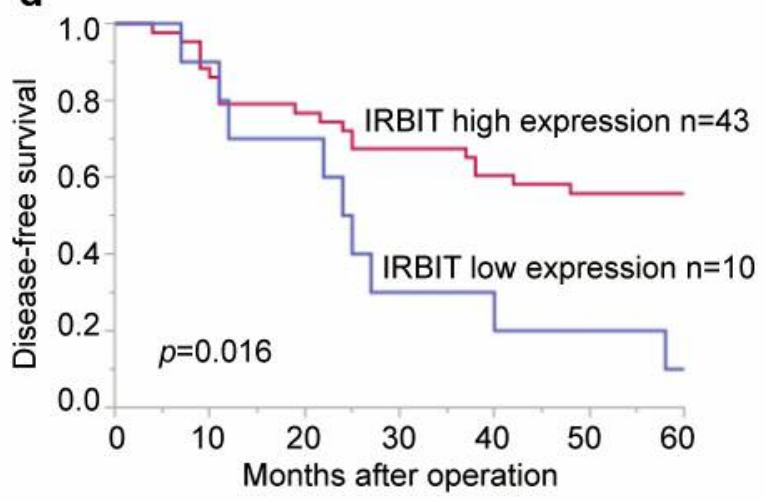

Figure 2. Kaplan-Meier analysis of five-year (a) overall and (b) disease-free survival in relation to IRBIT expression in patients who did not receive postoperative adjuvant therapy; in contrast, $(c)$ overall and $(d)$ disease-free survival in relation to IRBIT expression in patients who received postoperative chemotherapy.

Statistical analysis. Statistically significant differences were analyzed using a Mann-Whitney $U$-test for continuous variables and a chi-squared test for categorical variables. Survival rates were calculated using the Kaplan-Meier method, and statistical significance was determined using the $\log$ rank test. Univariate survival analyses were performed using the Cox proportional hazards model. A probability value of less than 0.05 was considered to be significant. All statistical analyses were performed using JMP Pro 12.0 software (SAS Institute Inc., Cary, NC, USA).

\section{Results}

Expression of IRBIT in clinical GC tissues. Immunohistochemistry was used to investigate the expression of IRBIT 
Table II. The relationship of clinicopathological factors and IRBIT expression in both groups of GC patients, those who were postoperatively treated with adjuvant chemotherapy and those who were not.

\begin{tabular}{|c|c|c|c|c|c|c|}
\hline \multirow[t]{3}{*}{ Factors } & \multicolumn{4}{|c|}{ Adjuvant chemotherapy (-) } & \multicolumn{2}{|c|}{ ljuvant chemotherapy (+) } \\
\hline & \multicolumn{6}{|c|}{ IRBIT } \\
\hline & $\begin{array}{l}\text { Low expression } \\
\qquad \mathrm{n}=16\end{array}$ & $\begin{array}{l}\text { High expression } \\
\quad \mathrm{n}=46\end{array}$ & $p$-Value & $\begin{array}{l}\text { Low expression } \\
n=10\end{array}$ & $\begin{array}{l}\text { High expression } \\
\quad n=43\end{array}$ & $p$-Value \\
\hline Age (years) & 68 & 69 & 0.76 & 65 & 58 & 0.07 \\
\hline \multicolumn{7}{|l|}{ Gender } \\
\hline Male & 12 & 35 & 0.93 & 5 & 25 & 0.64 \\
\hline Female & 4 & 11 & & 5 & 18 & \\
\hline \multicolumn{7}{|l|}{ Histology } \\
\hline Well, Moderate & 5 & 20 & 0.39 & 3 & 15 & 0.77 \\
\hline Poor, Signet & 11 & 26 & & 7 & 28 & \\
\hline Tumor size (mm) & 76 & 66 & 0.37 & 61 & 71 & 0.45 \\
\hline \multicolumn{7}{|l|}{ Depth } \\
\hline $\mathrm{m}, \mathrm{sm}, \mathrm{mp}$ & 4 & 5 & 0.19 & 1 & 6 & 0.73 \\
\hline ss, se, si & 12 & 41 & & 9 & 37 & \\
\hline \multicolumn{7}{|c|}{ Lymphatic metastasis } \\
\hline Absent & 4 & 12 & 0.93 & 1 & 5 & 0.88 \\
\hline Present & 12 & 34 & & 9 & 38 & \\
\hline \multicolumn{7}{|l|}{ Lymphatic invasion } \\
\hline Absent & 1 & 5 & 0.57 & 0 & 1 & 0.52 \\
\hline Present & 15 & 41 & & 10 & 42 & \\
\hline \multicolumn{7}{|l|}{ Venous invasion } \\
\hline Absent & 13 & 33 & 0.44 & 7 & 31 & 0.90 \\
\hline Present & 3 & 13 & & 3 & 12 & \\
\hline \multicolumn{7}{|l|}{ Stage } \\
\hline II & 9 & 25 & 0.90 & 3 & 15 & 0.77 \\
\hline III & 7 & 21 & & 7 & 28 & \\
\hline \multicolumn{7}{|l|}{ HER2 } \\
\hline Negative & 14 & 41 & 0.78 & 9 & 37 & 0.86 \\
\hline Positive & 1 & 4 & & 1 & 5 & \\
\hline
\end{tabular}

Well: Well differentiated; Moderate: moderately differentiated; Poor: poorly differentiated; Signet: signet ring cell.

in 115 GC specimens. Representative immunohistochemical staining pictures are shown in Figure 1. IRBIT was detected in the cytoplasm. Among 115 GC patients, 26 (22.6\%) were classified as having low-IRBIT expression (Figure 1a), and $89(77.4 \%)$ were assigned to the high-IRBIT-expression group (Figure 1b).

Relationship between IRBIT expression and clinicopathological features of GC patients. The relationships between the expression of IRBIT and clinicopathological features in 115 GC patients are shown in Table II. Regarding the postoperative adjuvant chemotherapy-free group, no statistical significance was found with clinicopathological features. There were also no significant associations between IRBIT expression and both overall survival and disease-free survival, as shown by the Kaplan-Meier analysis (Figure 2a and b). In contrast, regarding the group receiving postoperative adjuvant chemotherapy, a significant association was found between IRBIT expression and both overall survival $(p=0.0072)$ and disease-free survival
( $p=0.016$ ) by the Kaplan-Meier analysis (Figure 2c and d). However, the association between IRBIT expression and clinicopathological features was not statistically significant. On multivariate analyses, low expression of IRBIT in GC tissues was an independent prognostic factor of poor survival (relative Risk $=3.37,95 \% \mathrm{CI}=1.41-7.56, p=0.0076$ ), as was vascular invasion with postoperative adjuvant chemo-therapy in $53 \mathrm{GC}$ patients (Table III).

\section{Discussion}

In this study, we demonstrated that GC patients who were treated with postoperative adjuvant chemotherapy were associated with recurrence and poor prognosis, depending on the expression levels of IRBIT. Moreover, multivariate regression analysis demonstrated that IRBIT expression was an independent predictor of overall survival.

Previous studies have focused on the role of IRBIT in drug resistance against DNA-damaging drugs (10). Bonneau 
Table III. Results of univariate and multivariate analyses of clinicopathological factors affecting the overall survival rate following surgery with postoperative adjuvant chemotherapy in 53 GC patients

\begin{tabular}{|c|c|c|c|c|c|c|}
\hline \multirow[t]{2}{*}{ Clinicopathological variables } & \multicolumn{3}{|c|}{ Univariate analysis } & \multicolumn{3}{|c|}{ Multivariate analysis } \\
\hline & $\mathrm{RR}$ & $95 \% \mathrm{CI}$ & $p$-Value & $\mathrm{RR}$ & $95 \% \mathrm{CI}$ & $p$-Value \\
\hline Age $(<65 v s . \geq 65)$ & 0.92 & $0.42-2.05$ & 0.92 & & & \\
\hline Sex (male $v s$. female) & 1.23 & $0.58-2.69$ & 0.60 & & & \\
\hline Histology type (well, moderately vs. poor, signet) & 1.04 & $0.44-2.26$ & 0.93 & & & \\
\hline Depth (m, sm, mp vs. ss, se, si) & 2,22 & $0.66-13.8$ & 0.22 & & & \\
\hline Lymph node metastasis (absent $v s$. present) & 2.22 & $0.66-13.8$ & 0.22 & & & \\
\hline Vascular invasion (absent $v s$. present) & 2.95 & $1.36-6.23$ & $0.0072 *$ & 3.36 & $1.53-7.22$ & $0.0032 *$ \\
\hline IRBIT expression (low vs. high) & 2.86 & $1.22-6.22$ & $0.018^{*}$ & 3.37 & $1.41-7.56$ & $0.0076^{*}$ \\
\hline
\end{tabular}

RR: Relative risk; CI: confidence interval. ${ }^{*} p<0.05$.

et al. have shown that IRBIT possesses a protein phosphatase-1 binding site (8). Interestingly, protein phosphatase- 1 has been reported to mediate apoptosis via the dephosphorylation of Akt (19) and retinoblastoma protein $(20,21)$. These findings suggested that IRBIT is a target of protein phosphatase-1. In this study, we compared the postoperative adjuvant chemotherapy-free group with the group receiving postoperative adjuvant chemotherapy. No statistically significant association was found between clinicopathological features and recurrence. In addition, poor prognosis in the postoperative adjuvant chemotherapy-free group depended on the expression of IRBIT. However, a significant association was found between IRBIT expression and the presence of recurrence and prognosis in the group receiving postoperative adjuvant chemotherapy. Our results suggest that IRBIT is involved in chemotherapy resistance. Similarly to our results in GC, Jeong et al. have shown that IRBIT functions as a tumor suppressor in human epithelial ovarian cancer (9). Hence, low IRBIT may be predictive of a higher risk of GC recurrence in patients treated with postoperative adjuvant chemotherapy.

Arnaoutov and Dasso have shown that IRBIT knockdown lead to interphase length variability and accelerated mitotic progression in HeLa cells (22). This finding suggests that IRBIT controls cell-cycle progression. This study also suggests the possibility that the regulation of ribonucleotide reductase, which supplies the building blocks necessary for DNA synthesis and repair, controls genomic stability and ensures proper cell-cycle regulation by IRBIT. In this study, the most frequent postoperative chemotherapeutic regimens used were S-1 and 5-FU. Tegafur, one of the constituent elements of $\mathrm{S}-1$, is a prodrug of 5-fluorouracil (5-FU). 5-FU acts in several ways, but mainly as a thymidylate synthase inhibitor. Interfering with the action of this enzyme prevents the synthesis of pyrimidine thymidine, which is a nucleoside required for DNA replication. Both IRBIT and 5-FU with S1 were thought to be related to DNA replication. In light of these findings and our results, it was considered that the expression of IRBIT could induce the effect of 5-FU with S-1. Furthermore, IRBIT would be critical for developing personalized treatments for patients based on patient risk assessments.

Our study has several limitations. First, this study has a small sample size, which may bias the results of our study. Further large-scale clinical trials are needed to clarify the potential of IRBIT as a new predictive biomarker for postoperative chemotherapy. Second, we compared patients who did not receive postoperative adjuvant chemotherapy with those who did. Recently, S-1 plus oxaliplatin and capecitabine plus oxaliplatin as well as $\mathrm{S}-1$ have been approved as postoperative adjuvant chemotherapy for GC patients. Thus, other regimens of postoperative adjuvant chemotherapy also need to be evaluated.

In conclusion, we clarified that the low expression of IRBIT in GC tissues obtained from patients who had been treated with postoperative adjuvant chemotherapy was associated with recurrence and poor prognosis. IRBIT could be useful as a predictive marker for chemotherapy.

\section{Conflicts of Interest}

The Authors declare that they have no conflict of interest regarding this study.

\section{Authors' Contributions}

Conception and design: N. Nakazawa, K. Ogata, and T. Yokobori; Acquisition of data: N. Nakazawa, S. Baatar, Y. Ubukata, A. Kimura, and N. Kogure; Analysis and interpretation of data: N. Nakazawa, K. Ogata, T. Yokobori, and K. Shirabe; Writing, review, and/or revision of the manuscript: N. Nakazawa, K. Ogata, T. Yokobori, M. Sohda, H. Kuwano, H. Saeki, and K. Shirabe; Material support: M. Ide; Study supervision: K. Ogata, T. Yokobori, M. Sohda, H. Kuwano, H. Saeki, and K. Shirabe. All Authors have read and approved the final manuscript. 


\section{Acknowledgements}

The Authors would like to thank Ms. Yukie Saito, Ms. Sayaka Okada, Ms. Kayoko Takahashi, Ms. Mizue Murata, Ms. Harumi Kanai, Ms. Fumie Takada, Ms. Sawa Nagayama, and Ms. Mariko Nakamura for their excellent assistance.

\section{References}

1 Torre LA, Bray F, Siegel RL, Ferlay J, Lortet-Tieulent J and Jemal A: Global cancer statistics, 2012. CA Cancer J Clin 65(2): 87-108, 2015. PMID: 25651787. DOI:10.3322/caac. 21262

2 Yamashita K, Sakuramoto S, Nemoto M, Shibata T, Mieno H, Katada N, Kikuchi S and Watanabe M: Trend in gastric cancer: 35 years of surgical experience in Japan. World J Gastroenterol 17(29): 3390-3397, 2011. PMID: 21876631. DOI: 10.3748/ wig.v17.i29.3390

3 Cao J, Qi F and Liu T: Adjuvant chemotherapy after curative resection for gastric cancer: a meta-analysis. Scand $J$ Gastroenterol 49(6): 690-704, 2014. PMID: 24731211. DOI: $10.3109 / 00365521.2014 .907337$

4 Ando H, Mizutani A, Matsu-ura T and Mikoshiba K: IRBIT, a novel inositol 1,4,5-trisphosphate (IP3) receptor-binding protein, is released from the IP3 receptor upon IP3 binding to the receptor. J Biol Chem 278(12): 10602-10612, 2003. PMID: 12525476. DOI: $10.1074 /$ jbc.M210119200

5 Ando H, Mizutani A, Kiefer H, Tsuzurugi D, Michikawa T and Mikoshiba K: IRBIT suppresses IP3 receptor activity by competing with IP3 for the common binding site on the IP3 receptor. Mol Cell 22(6): 795-806, 2006. PMID: 16793548. DOI: $10.1016 /$ j.molcel.2006.05.017

6 Devogelaere B, Nadif Kasri N, Derua R, Waelkens E, Callewaert G, Missiaen L, Parys JB and De Smedt H: Binding of IRBIT to the IP3 receptor: determinants and functional effects. Biochem Biophys Res Commun 343(1): 49-56, 2006. PMID: 16527252. DOI: $10.1016 /$ j.bbrc.2006.02.119

7 Berridge MJ, Bootman MD and Roderick HL: Calcium signalling: dynamics, homeostasis and remodelling. Nat Rev Mol Cell Biol 4(7): 517-529, 2003. PMID: 12838335. DOI: 10.1038/nrm1155

8 Bonneau B, Ando H, Kawaai K, Hirose M, Takahashi-Iwanaga $\mathrm{H}$ and Mikoshiba K: IRBIT controls apoptosis by interacting with the Bcl-2 homolog, Bcl2110, and by promoting ERmitochondria contact. eLife 5: e19896, 2016. PMID: 27995898. DOI: $10.7554 / \mathrm{eLife} .19896$

9 Yang D, Shcheynikov N, Zeng W, Ohana E, So I, Ando H, Mizutani A, Mikoshiba $\mathrm{K}$ and Muallem S: IRBIT coordinates epithelial fluid and $\mathrm{HCO}_{3}^{-}$secretion by stimulating the transporters pNBC1 and CFTR in the murine pancreatic duct. J Clin Invest 119: 193-202, 2009. PMID: 19033647. DOI: 10.1172/JCI36983

10 Lee SK, Boron WF and Parker MD: Relief of autoinhibition of the electrogenic $\mathrm{Na} / \mathrm{HCO}_{3}$ cotransporter $\mathrm{NBCe} 1-\mathrm{B}$ : role of IRBIT versus amino-terminal truncation. Am J Physiol Cell Physiol 302(3): 518-526, 2012. PMID: 22012331. DOI: 10.1152/ ajpcell.00352.2011

11 Hong JH, Yang D, Shcheynikov N, Ohana E, Shin DM and Muallem S: Convergence of IRBIT, phosphatidylinositol $(4,5)$ bisphosphate, and WNK/SPAK kinases in regulation of the $\mathrm{Na}^{+}$$\mathrm{HCO}_{3}{ }^{-}$cotransporters family. Proc Natl Acad Sci USA 110(10):
4105-4110, 2013. PMID: 23431199. DOI: 10.1073/pnas. 1221410110

12 Jeong W, Kim HS, Kim YB, Kim MA, Lim W, Kim J, Jang HJ, Suh DH, Kim K, Chung HH, Bazer FW, Song YS, Han JY and Song G: Paradoxical expression of AHCYL1 affecting ovarian carcinogenesis between chickens and women. Exp Biol Med (Maywood) 237(7): 758-767, 2012. PMID: 22826361. DOI: 10.1258/ebm.2012.011433

13 Wittig R, Nessling M, Will RD, Mollenhauer J, Salowsky R, Münstermann E, Schick M, Helmbach H, Gschwendt B, Korn B, Kioschis P, Lichter P, Schadendorf D and Poustka A: Candidate genes for cross-resistance against DNA-damaging drugs. Cancer Res 62(22): 6698-6705, 2002. PMID: 12438269.

14 Shirasaka T, Shimamato Y, Ohshimo H, Yamaguchi M, Kato T, Yonekura $\mathrm{K}$ and Fukushima M: Development of a novel form of an oral 5-fluorouracil derivative (S-1) directed to the potentiation of the tumour selective cytotoxicity of 5-fluorouracil by two biochemical modulators. Anti-Cancer Drugs 7(5): 548-557, 1996. PMID: 8862723.

15 Sakuramoto S, Sasako M, Yamaguchi T, Kinoshita T, Fujii M, Nashimoto A, Furukawa H, Nakajima T, Ohashi Y, Imamura H, Higashino M, Yamamura Y, Kurita A and Arai K; ACTS-GC Group: Adjuvant chemotherapy for gastric cancer with S-1, an oral fluoropyrimidine. N Engl J Med 357(18): 1810-1820, 2007. PMID: 17978289. DOI: 10.1056/NEJMoa072252

16 Sasako M, Sakuramoto S, Katai H, Kinoshita T, Furukawa H, Yamaguchi T, Nashimoto A, Fujii M, Nakajima T and Ohashi Y: Five-year outcomes of a randomized phase III trial comparing adjuvant chemotherapy with S-1 versus surgery alone in stage II or III gastric cancer. J Clin Oncol 29(33): 4387-4393, 2011. PMID: 22010012. DOI: 10.1200/JCO.2011.36.5908

17 Japanese Gastric Cancer Association: Japanese Classification of Gastric Carcinoma: 3rd English edition. Gastric Cancer 14: 101112, 2011. PMID: 21573743. DOI: 10.1007/s10120-011-0041-5

18 Allred D, Harvey JM, Berardo M and Clark GM: Prognostic and predictive factors in breast cancer by immunohistochemical analysis. Mod Pathol 11(2): 155-168, 1998. PMID: 9504686.

19 Thayyullathil F, Chathoth S, Shahin A, Kizhakkayil J, Hago A, Patel $\mathrm{M}$ and Galadari S: Protein phosphatase 1-dependent dephosphorylation of Akt is the prime signaling event in sphingosine-induced apoptosis in Jurkat cells. J Cell Biochem 112(4): 1138-1153, 2011. PMID: 21308747. DOI: 10.1002/ jcb. 23033

20 Puntoni F, Villa-Moruzzi E: Protein phosphatase-1 activation and association with the retinoblastoma protein in colcemid-induced apoptosis. Biochem Biophys Res Commun 266(1): 279-283, 1999. PMID: 10581203. DOI: 10.1006/bbrc.1999.1800

21 Wang RH, Liu CW, Avramis VI and Berndt N: Protein phosphatase 1alpha-mediated stimulation of apoptosis is associated with dephosphorylation of the retinoblastoma protein. Oncogene 20(43): 6111-6122, 2001. PMID: 11593419. DOI: 10.1038/sj.onc.1204829

22 Arnaoutov A and Dasso M: Enzyme regulation. IRBIT is a novel regulator of ribonucleotide reductase in higher eukaryotes. Science 345(6203): 1512-1515, 2014. PMID: 25237103. DOI: $10.1126 /$ science. 1251550

Received May 24, 2019

Revised June 14, 2019

Accepted June 18, 2019 